Table 1

\begin{tabular}{|c|c|c|c|c|} 
Year & $\begin{array}{c}\text { Receipts } \\
\text { (rounded to } \\
\text { nearest } \\
\text { thousand) Rs. }\end{array}$ & $\begin{array}{c}\text { Expenditure } \\
\text { (rounded to } \\
\text { nearest } \\
\text { thousand) Rs. }\end{array}$ & $\begin{array}{c}\text { No. of } \\
\text { students }\end{array}$ & $\begin{array}{c}\text { No. of } \\
\text { members } \\
\text { of staff }\end{array}$ \\
\hline 1911 & $20,68,000$ & $15,99,000$ & 24 & 6 \\
1919 & $3,24,000$ & $3,41,000$ & 73 & 7 \\
1939 & $6,58,000$ & $6,08,000$ & 187 & 20 \\
1947 & $32,06,000$ & $36,67,000$ & 221 & 50 \\
1953 & $58,65,000$ & $54,14,000$ & 373 & 123 \\
1958 & $64,05,000$ & $66,64,000$ & 561 & 157 \\
\hline
\end{tabular}

country for advanced instruction and research in science and engineering, the Institute took up for investigation during the Second World War a large number of schemes of research sponsored by the Council of Scientific and Industrial Research, the Indian Council of Agricultural Research, the Indian Council of Medical Research and the Governments of Madras and Mysore. During that period, the Institute planned and established a Department of Aeronautical Engineering. When the War was drawing to a close, a further four-year expansion programme was launched with grants sanctioned by tho Contral Government. Under that programme, the Departments of Metallurgy (1945), Internal Combustion Fngineering (1945), and Chemical Technology and Chemical Engineering (1951) were established; and laboratories for research in fermentation technology, food technology and pharmacology were set up. For the training of power engineers, a Department of Power Engineering was established in 1947 with laboratories for electrical, mochanical, civil and hydraulic and high-voltage engineering. A Section of Economics and Industrial Psychology, including industrial relations, and affording facilities for research in these subjects, was also started in the same year.

In 1955, under a scheme for the development of facilities for technical education, additional postgraduate courses in automobile engineering (1956), foundry engineering (1956), soil mechanics and foundation engineering (1957), electronic engineering (1956), ultra-short and microwave engineering (1956), line communication engineering and acoustical engineering were provided. Further facilities for research in technical gas reactions, physical metal lurgy, hydraulic machines, internal combustion engineering, electrical measurements and measuring instruments, transmission, distribution and network practice have been added. Recently, a Department of Applied Mathematics and a Section of Industrial Engineering and Administration have been established.

The Library of the Institute is one of the best scientific and technical libraries in India.

The Institute publishes a quarterly entitled Journal of the Indian Institute of Science, containing original papers by the research workers of the Institute.

A noteworthy feature of the Indian Institute of Science is the objective itself with which it was founded, namely, for the provision of advanced instruction and the conduct of original investigations in all branches of knowledge that are likely to promote the material and industrial welfare of India. The broader the objective, obviously the more difficult will it be of fulfiment. However, the facts that we started with good foundations and established at a very early stage traditions of research in pure sciences like physics and chemistry, that we added later, and at appropriate times, specialized branches of technology like power engineering, metallurgy and aeronauties, and also that we did not quite neglect mathematics and even the humanities are, in my opinion, the principles that helped us to face our task and make its fulfilment come as near the ideal laid down by the founder as possible.

During the past fifty years, the Institute has grown to be one of the foremost centres of scientific research and advanced instruction in India. A large low-speed open-circuit wind tunnel of $9 \mathrm{ft}$. $\lambda 14 \mathrm{ft}$. test section was inaugurated during the recent jubilee celebrations. This tunnel is the only one of $j$ ts kind in India, and will offer increased instructional and research facilities in aeroplane design. A modern a.c. network analyser, again the only one of its kind in India, has been in use for some time now in connexion with studies relating to power systems in the country. We are planning to put up and equip a modern acoustical laboratory to serve the purpose of training, research and testing in all branches of acoustics. There are many other lines of development which are not mentioned here for want of space. The Institute's contribution to the instructional aspect is reflected in the fact that more than three thousand of its alumni are now occupying positions of importance and responsibility all over the country in their fields of specialization. The research work done at the Institute has opened a new vista for generations of Indian scientists and engineers who go through its portals. Many young men and women from different parts of the country now eagerly look forward to joining the band of workers at the Institute.

The Institute is, to a high degree, autonomous in character. In the past, we confined ourselves to research and training, largely at the postgraduate level, and we propose to retain this feature in the year's ahead. Thus we are able to direct our technological and scientific resources to carefully chosen specific purposes. We hope that against this back. ground the Institute and those associated with it will have a great part to play in promoting the progress of India.

\title{
OBITUARIES
}

\section{Sir J. C. Ghosh}

Sir J JAN Chandra Ghosh died suddenly at the age of sixty-four at his Calcutta residence on January 21. I had been closely associated with him for some fifty years.

Sir J. C. Ghosh was a leader in physical chemistry when he was the professor and head of the Chemistry Department of the University of Dacca, which he joined in 1921, being appointed in London by Sir Philip Hartog, the first vice-chancellor of the University. He served this University lovally for twenty years and with conspicuous success as a teacher and research worker. By his devotion to science and his kindly nature, he attracted many young men and initiated them into scientific research. This seems to have been the best period in his career in the service of science and education. 
In 1915 Ghosh published his first paper on the electrolysis of solutions by alternating electric current in the Journal of the American Chemical Society. During the First World War, Snethlage (Z. phys. Chem., 90, 1, 139; 1915) published some papers criticizing the Arrhenius electrolytic dissociation theory. I pointed out the weakness of Snethlage's views (Medd. Nobel Inst., 3, No. 15; 1916), and later developed my views in a paper to the Faraday Society, and a general discussion on the present position of the theory of ionization was organized in Jondon by the Faraday Society on January 21, 1919. In this general discussion Ghosh's contributions to the basic conception of total ionization of electrolytes wero considered and discussed and were favourably received by leading physical chemists of Britain, and papers by him were published in the Journal of the Chemical Society, London. However, other physical chemists scrutinized the conceptions and arguments of Ghosh and pointed out that they were not valid. Although Sutherland (Phil. Mag., 3, $161 ; 1902 ; 12,1 ; 1906$ ) and Milner (ibid., 25, 742; 1913 ) introduced the conception of complete ionization, Ghosh's papers were mainly responsible for the development of this idea and its applications by Debye and Hückel in their theory of strong electrolytes. Later, Ghosh and his collaborators published some interesting papers on catalytic gaseous reactions and photochemistry, which have been followed up elsowhere.

During the Second World War, Ghosh was appointed director of the Indian Institute of Science, Bangalore, which expanded in various directions during his regime. In this period he was knighted, chiefly for his war services.

When Dr. Shyama Prosad Mukherji was appointed Minister in the Union Government, he took Ghosh to Delhi to assist in the expansion of technology in India. After a short stay in Delhi, he was sent to be the first director of the Indian Tochnological Institute at Kharagpur, West Bengal. Then he was appointed the first whole-time vice-chancellor of the University of Calcutta; but he had to give up this post after a short time on his appointment as a member of the Planning Commission for Science and Technology in India.

Lady Ghosh, three sons and two daughter's survive him. N. R. DHAR

\section{Prof. W. Riddet}

Prof. Winliam Riddet, director of the Dairy Research Institute (N.Z.) at Palmerston North, New Zealand, died on December 30 at the age of sixty-two.

Prof. Riddet was born of farming parents in Ayrshire, Scotland. $\mathrm{He}$ graduated B.Sc. and N.D.A., N.D.D. (with honours) at the West of Scotland Agricultural College and the University of Glasgow. In 1921 he joined the staff of the West of Scotland Agricultural Colloge, first as dairy instructor and later as lecturer. In 1925 he migrated to New Zealand to take up the then recently established Logan Campbell ehair of agriculture at Anckland University College. In co-operation with Prof. G. S. (now Sir Geoffrey) Peren, then Walter Buchanan professor of agriculture at Victoria University College, Wellington, he organized the establishment, in 1927, of Massey Agricultural College, at Palmerston North, to which both professorships were transferred. At about the same time he played a leading part in the arrangements for the development of the Dairy Research
Institute (N.Z.), an organization set up undor the agis of the N.Z. Department of Seientific and Industrial Research to undertake scientific research work as a service to the rapidly expanding dairy products manufacturing industry. Prof. Riddet was appointed the first director of this Institute.

Thus it was in the dual role of dean of dairying (and lator vice-principal) of Massey Agricultural College and director of the Dairy Research Institute (N.Z.) that Prof. Riddet made his outstanding contribution to the advancement of dairy science and dairy practice, and thereby to the general welfare and prosperity of his adopted country.

Prof. Riddet had from the outset that very important attribute of a leader in teaching and research, an original and ranging mind. His interests covered a wide field; and wherever his interest lay his mind was active in devising and fostering ideas for investigation and research. Endowed with what seemed to be an inexhaustible reserve of energy, he devoted himself to his duties with an astonishing persisteney.

As a teacher he set for his students very exacting standards. The value of his teaching is shown in the calibre of the men who came under his influence-... they are to bo found occupying positions of high responsibility in New Zealand, in Great Britain, and in many other countries. His spirit lives in the training and inspiration he has passed on to these students.

It lives, too, in the organization which he controlled from its beginnings, the Dairy Research Institute (N.Z.). Under his guidance the Institute has gained an international reputation for its work on a number of aspects of dairying practice. While the publications describing this work do not often carry his name as author or co-author, all those who have worked under him will readily acknowledge their debt to him. With typical generosity he made no claims, and passed on his ideas without reserva. tion. It was for him sufficient recompenso that he could see the work being done and the Institute serving well the industry from which it drew its support.

The impact of Riddet's personality on the teaching of agricultural science, and on the dairy farming and dairy products manufacturing industry in New Zealand, will be evident for many years to come.

F. F. MCDOWALI

\section{Mr. F. W. James}

ON January 27, Mr. Francis Wogan James, librarian to the Imperial College of Science and Technology, London, died after years of illness most bravely and eheerfully borne.

From Haverfordwest he went to the Royal College of Science as a Royal Scholar in 1930, and after taking his degree in 1933 he became a research student in inorganic chemistry. During 1936-38 he was research assistant to the professor of highway engineering in the Department of Civil Engineering of the City and Guilds College-a transfer from one to another of the constituent parts of the Imperial College which made it easy for him, in later ycars, to take a broad view of the needs of the whole College.

In 1938 'Frank' James asked the Dean of the City and Guilds College for permission to apply for the post of College librarian-an appointment which, academically and financially, was junior to the ono he was holding-in order to be in a better position 